\title{
Pengambilan Keputusan Strategis Pemasaran di Perguruan Tinggi dengan menggunakan Analytics Hierarchy Process (AHP)
}

\author{
http://dx.doi.org/10.28932/jutisi.v6i2.2748 \\ Arie Tunggal ${ }^{\# 1}$, Setia Budi ${ }^{\bowtie \# 2}$,

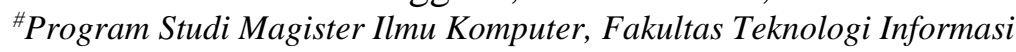 \\ Universitas Kristen Maranatha \\ Jl. Prof. drg. Surya Sumantri No.65 Bandung \\ ${ }^{1}$ arie.tunggal emaranatha . edu \\ 2 setia.budieit.maranatha.edu
}

\begin{abstract}
In marketing strategies, it is very important to consider various variables in decision making. With intense competition in higher education, it is important to determine a more appropriate and effective marketing strategy to get prospective students. For this reason, it is necessary to investigate what factors influence prospective students in determining tertiary institutions. This study reveals that the most influencing factors for prospective students in determining academic institutions are the ease of getting a job after graduation, followed by some other supporting factors, such as: scholarships, campus reputation, spiritual activities, and campus lifestyle.
\end{abstract}

Keywords - Analytics hierarchy process; decision making; higher education; marketing strategy; multi-criteria decision making.

\section{Pendahuluan}

\section{A. Latar Belakang}

Saat ini banyak bermunculan perguruan tinggi baru di Indonesia, baik perguruan tinggi negeri (PTN) maupun perguruan tinggi swasta (PTS). Seperti pada Gambar 1, perbandingan jumlah perguruan tinggi swasta di Indonesia mencapai 3.154 PTS.

Hal ini ditambah dengan masuknya perguruan tinggi asing yang menawarkan program kesarjanaan dari luar negeri, tentunya persaingan antar perguruan tinggi terutama bagi PTS menjadi semakin ketat.

Situasi ini menjadi semakin sulit mengingat jumlah siswa Sekolah Menengah Atas (SMA) yang lulus serta melanjutkan pendidikan ke perguruan tinggi tidak mengalami penambahan yang signifikan. Hal ini dapat dilihat pada Gambar 2 yang memperlihatkan jumlah mahasiswa setiap tahunnya dari tahun 1997-2018.

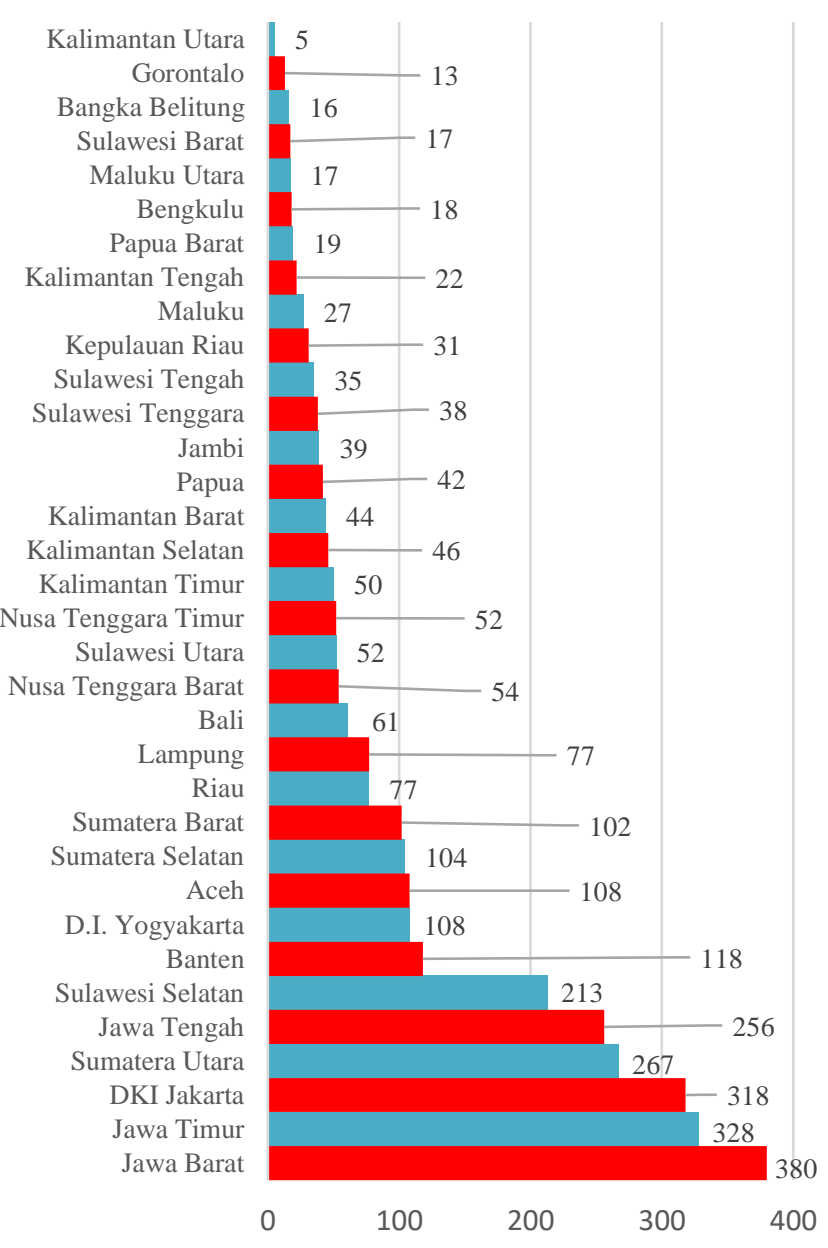

Gambar 1. Perguruan Tinggi Swasta di Indonesia pada Tahun 2018 [1]

Bagi perguruan tinggi swasta, sumber dana operasional diperoleh dari mahasiswa, hibah, sponsor, yayasan atau 
pemilik perguruan tinggi. Tetapi sebagian besar, mahasiswa menjadi salah satu sumber dana terbesar untuk menopang seluruh operasional di sebuah perguruan tinggi, terutama perguruan tinggi swasta. Sehingga perlu dijaga komposisi mahasiswa yang aktif dan masuknya mahasiswa baru secara jumlah (student body). Untuk itu, perguruan tinggi swasta perlu menerapkan strategi pemasaran yang tepat dan sesuai sasaran.

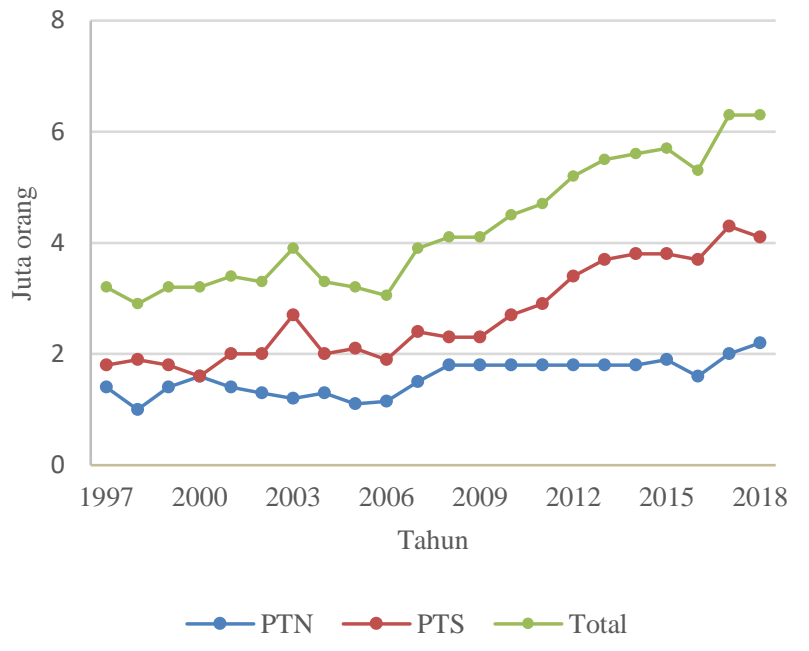

Gambar 2. Jumlah Mahasiswa di Indonesia dari Tahun 1997-2018 [2]

Dalam memilih perguruan tinggi, calon mahasiswa tidak hanya memilih berdasarkan Program Studi yang diminati saja, tetapi ada faktor-faktor lain yang menjadi pertimbangannya. Faktor-faktor pertimbangan ini yang akan dijadikan variabel dalam perhitungan metode Analytics Hierarchy Process (AHP) agar lebih tepat dalam menentukan kriteria apa yang berpengaruh di suatu kota. Dengan mengetahui kriteria yang mempengaruhi calon mahasiswa di suatu kota, kriteria ini akan menjadi salah satu cara yang dapat digunakan untuk mendapatkan calon mahasiswa dengan tepat, karena dapat menjawab kebutuhan dari calon mahasiswa.

Dari hasil penelitian ini, diharapkan dalam menentukan target pasar atau calon mahasiswa dapat menggunakan cara yang lebih tepat.

\section{B. Rumusan Masalah}

Pimpinan perguruan tinggi dalam mengambil keputusan menentukan strategi membutuhkan masukan dari data-data yang dimiliki, agar keputusan yang diambil dapat sesuai dengan tujuan perusahaan. Maka perlu menentukan rumusan masalah dari kendala yang dihadapi, yaitu:

1. Bagaimana mengetahui kriteria apa saja yang mempengaruhi calon mahasiswa memilih perguruan tinggi di kota tersebut?

2. Bagaimana memastikan bahwa data yang digunakan ini telah konsisten?

3. Bagaimana cara meningkatkan jumlah calon mahasiswa yang berasal dari kota yang menjadi target pasar?
Pada penelitian ini pun dibatasi ruang lingkupnya pada salah satu PTS di Jawa Barat, dimana persaingan paling besar dari semua perguruan tinggi terletak di Jawa Barat, dengan jumlah PTS yang paling banyak di Indonesia.

\section{Tujuan Penelitian}

Berdasarkan penelitian yang ada, maka tujuan dari penelitian ini adalah sebagai berikut:

1. Menentukan kriteria apa saja yang mempengaruhi calon mahasiswa memilih perguruan tinggi di suatu kota.

2. Mengukur dan memastikan konsistensi data yang digunakan.

3. Menentukan kriteria yang paling tepat ditawarkan di kota tersebut.

\section{KAJIAN TEORI}

A. Strategi Pemasaran di Perguruan Tinggi

Menerapkan strategi pemasaran di perguruan tinggi telah menjadi perhatian pimpinan perguruan tinggi, terutama di perguruan tinggi swasta pada saat ini. Oleh karena itu, perlu menentukan strategi pemasaran yang tepat untuk menambah jumlah calon mahasiswa yang mendaftar. Berdasarkan $\mathrm{K}$. Seehanate [3], di dalam strategi pemasaran di perguruan tinggi terbagi 3 kategori besar, yaitu karakter dari calon mahasiswa, faktor lingkungan dan faktor mix marketing atau 7P, yaitu product, price, physical evidence, people, process, place dan promotion, seperti pada Gambar 3.

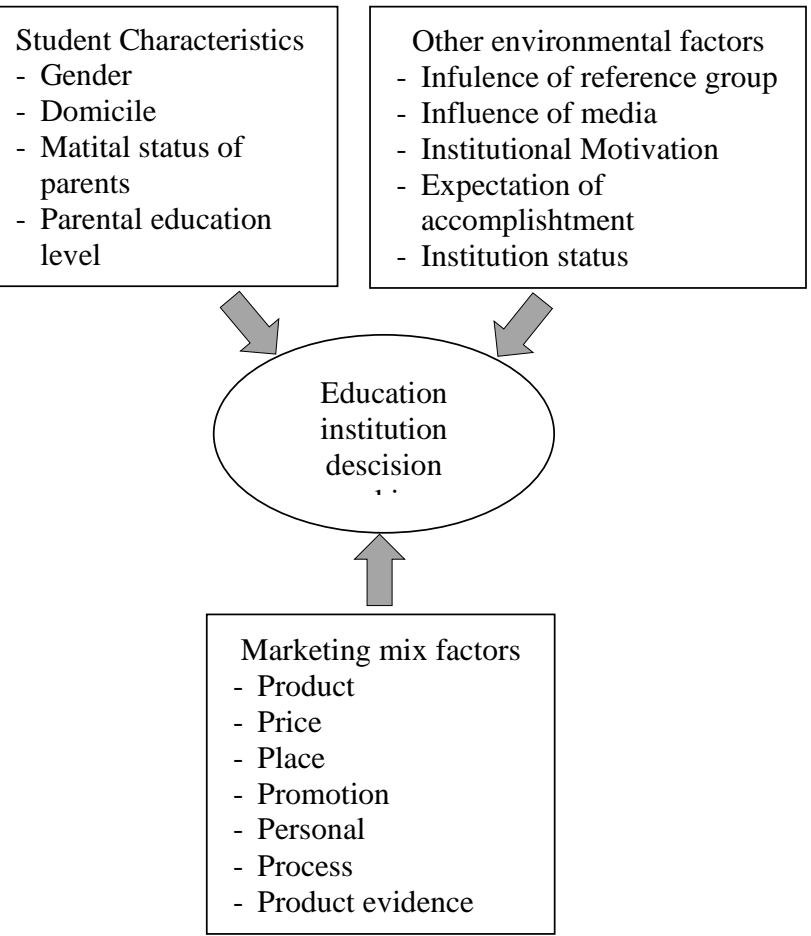

Gambar 3 Kerangka Konseptual Pemasaran di Perguruan Tinggi

Selain itu, menurut A.M. Kalimullina dan S.G. Dobrotvorskaya [4], untuk calon mahasiswa sebelum 
memulai memilih perguruan tinggi terdapat beberapa faktor yang mempengaruhi, yaitu:

1. Komunikasi dengan calon mahasiswa.

2. Karakteristik pribadi calon mahasiswa.

3. Tempat tinggal calon mahasiswa.

4. Keadaan ekonomi.

5. Media massa.

6. Tingkat kesadaran terhadap mutu pendidikan.

7. Pengalaman profesional.

8. Beasiswa.

9. Sarana kampus.

10. Metode pengajaran.

Semua faktor-faktor ini menjadi pertimbangan calon mahasiswa dalam memilih perguruan tinggi untuk melanjutkan pendidikannya secara umum.

\section{B. Multi-Criteria Decision Analysis (MCDA)}

MCDA atau biasa dikenal dengan Multi-Criteria Decision Making (MCDM) adalah disiplin yang ditujukan untuk mendukung pengambilan keputusan yang dihadapkan dengan banyaknya variabel dan evaluasi yang saling bertentangan. MCDA bertujuan menyoroti konflik-konflik dan menurunkannya dengan cara kompromi dalam proses yang transparan [5]. Beberapa model MCDA adalah Analytic Hierarchy Process, Inner Product of Vectors, Multi-attribute value theory, Multi-attribute utility theory, Multi-attribute global inference of quality, Goal programming, ELECTRE, PROMETHEE, Data Envelopment Analysis, The Evidential reasoning approach, Dominance-based Rough Set Approach, Aggregated Indices Randomization Method, Nonstructural Fuzzy Decision Support System, Grey Relational Analysis, Superiority and Inferiority Ranking Method [6].

Pada penelitian ini akan menggunakan salah satu metode MCDA yaitu Analytic Hierarchy Process atau biasa dikenal dengan AHP.

\section{Analytics Hierarchy Process (AHP)}

AHP adalah teknik terstruktur untuk menangani keputusan yang kompleks. Berdasarkan matematika dan psikologi, AHP dikembangkan oleh Thomas L. Saaty [7] pada tahun 1970-an dan terus disempurnakan.

AHP menyediakan kerangka kerja yang komprehensif dan rasional untuk menyusun masalah keputusan, mewakili dan mengukur setiap elemennya dan metode ini telah digunakan di berbagai bidang seperti pemerintah, bisnis, industri, kesehatan dan pendidikan. Metode ini juga menggabungkan kekuatan dari perasaan dan logika yang bersangkutan pada berbagai persoalan, lalu mensintesiskan menjadi hasil yang cocok dengan perkiraan kita secara intuitif.

AHP dapat digunakan untuk menyelesaikan banyak masalah khusus dan kompleks yang dihadapi manajemen Pemasaran. Masalah-masalah kompleks yang dibahas meliputi [8]:
1) Merekonsiliasi berbagai tujuan yang saling bertentangan, di bawah sumber daya yang ada.

2) Mengelola sejumlah besar data.

3) Berurusan dengan data subjektif dan objektif untuk membuat keputusan.

4) Mengelola untuk menyelesaikan konflik di antara tim multidisiplin.

Pemilihan pasar sasaran digunakan untuk memilih satu atau lebih segmen pasar, sehingga suatu organisasi dapat memaksimalkan keuntungan. Secara umum, ada tiga jenis target pemilihan pasar, yaitu pemasaran massal (undifferentiated marketing) dimana umumnya digunakan di situasi dengan pelanggan memiliki karakteristik yang sama, pemasaran tertarget (differentiated marketing) adalah memisahkan pasar menjadi kelompok pelanggan dengan keinginan dan kebutuhan yang agak berbeda. Pemasaran ceruk (concentrated segmentation marketing) yang berfokus pada jumlah pelanggan yang relatif kecil di pasar atau konsumen yang memiliki karakteristik tertentu [9]. Pada penelitian ini akan menggunakan pemasaran tertarget atau differentiated marketing.

Untuk membuat keputusan secara terorganisir dan menghasilkan prioritas, maka perlu mengikuti langkahlangkah seperti pada Gambar 4 [7].

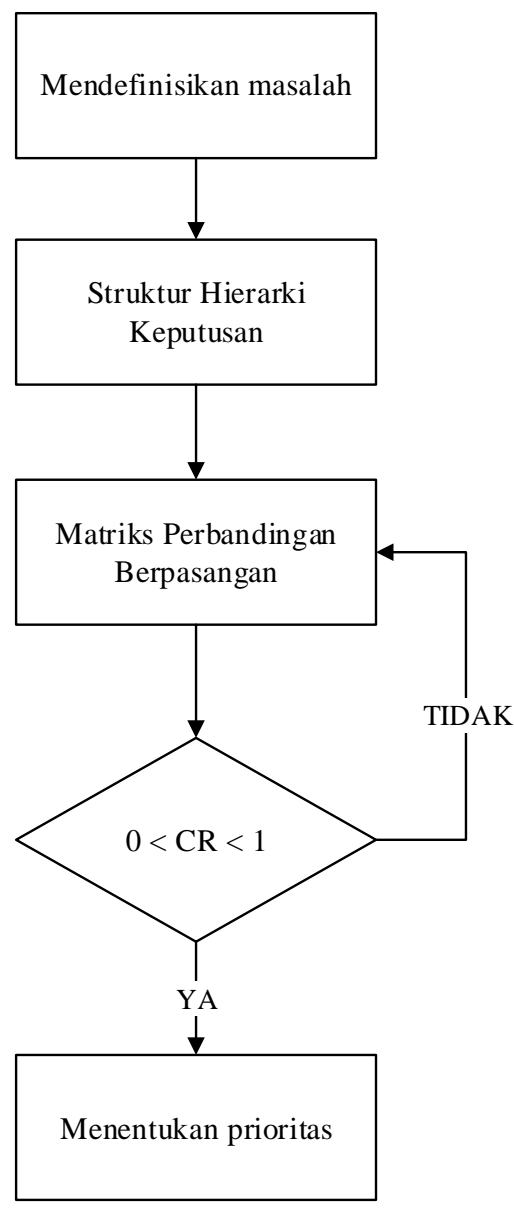

Gambar 4 Langkah-langkah Metode AHP 


\section{ANALISIS DAN PERANCANGAN SISTEM}

Untuk memperoleh hasil data yang dibutuhkan pada penelitian ini, maka menggunakan hasil survei dari data calon mahasiswa yang mendaftar selama 2 (dua) tahun terakhir, yaitu tahun 2018 dan 2019. Dari 13 (tiga belas) pilihan faktor yang mempengaruhi calon mahasiswa dalam memilih perguruan tinggi, dipilih 5 (lima) faktor terbanyak dari masing-masing kota. Dengan kota yang akan dijadikan target pasar adalah Ambon, Kupang, Manado, Pekanbaru dan Pontianak.

Dari hasil survei pada Tabel I, lima kriteria yang paling mempengaruhi dalam memilih perguruan tinggi oleh calon mahasiswa adalah memiliki kenalan di kampus, kemudahan mendapat kerja, reputasi kampus, beasiswa dan kegiatan rohani.

TABEL I

HASIL SURVEI CALON MAHASISWA

\begin{tabular}{|c|c|c|c|c|c|}
\hline $\begin{array}{l}\text { Hasil } \\
\text { Survei }\end{array}$ & 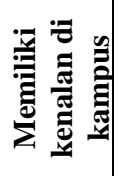 & 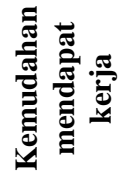 & 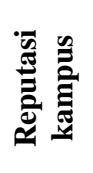 & 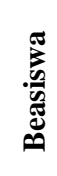 & 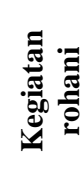 \\
\hline Ambon & 3 & 11 & 3 & 5 & 31 \\
\hline Kupang & 2 & 2 & 7 & 6 & 28 \\
\hline Manado & 4 & 24 & 19 & 16 & 50 \\
\hline Pekanbaru & 13 & 51 & 25 & 18 & 40 \\
\hline Pontianak & 5 & 18 & 21 & 8 & 33 \\
\hline
\end{tabular}

Dari Gambar 5 memperlihatkan, bahwa kegiatan rohani merupakan faktor yang paling banyak dipilih menjadi pertimbangan calon mahasiswa, disusul dengan kemudahan mendapat kerja dan reputasi kampus. Sedangkan untuk faktor beasiswa dan memiliki kenalan di kampus tidak terlalu banyak. Hal ini menunjukkan bahwa ada karakteristik khusus dari calon mahasiswa saat ini untuk memilih perguruan tinggi, karena kegiatan rohani menjadi yang terbanyak dari hasil survey. Untuk itu dalam penelitian ini, hasil survei ini menjadi hipotesa awal dalam menentukan faktor yang menentukan calon mahasiswa dalam memilih perguruan tinggi.

Sebelum memulai perhitungan dengan metode AHP, perlu diketahui ada beberapa prinsip dasar dalam menyelesaikan permasalahan yang perlu dilakukan, yaitu

1) Mendefinisikan masalah: dengan mengetahui jelas masalah yang ingin dipecahkan akan membantu dalam menentukan pengetahuan yang perlu dicari.

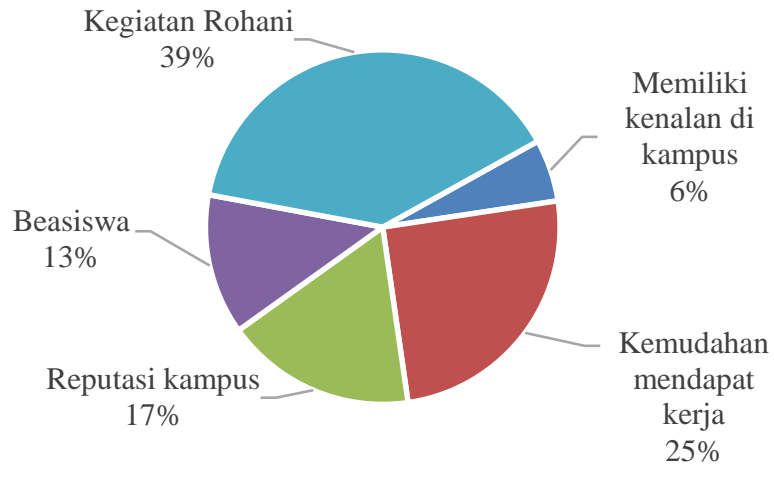

Gambar 5. Hasil 5 (lima) tertinggi alasan calon mahasiswa mencari perguruan tinggi

2) Struktur hirarki keputusan: untuk memisahkan atau memecahkan masalah yang kompleks menjadi elemenelemen pendukung, dari level atas yaitu tujuan keputusan, level menengah yang bergantung pada unsur-unsur lainnya hingga level terendah. Pada Gambar 6 dapat dilihat struktur hirarki dari masing-masing level, dimana level pertama adalah memilih perguruan tinggi, dilanjutkan dengan level 2 adalah faktor yang mempengaruhi, serta level 3 adalah kota yang menjadi target pasar.

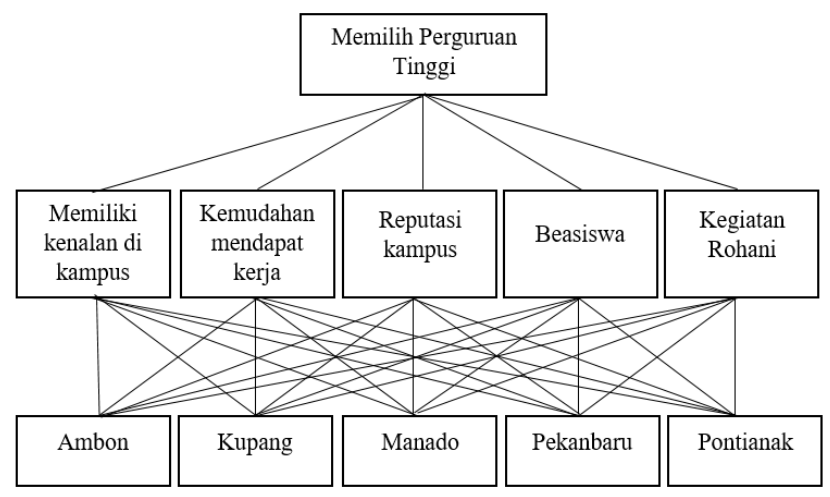

Gambar 6 Struktur Hirarki Pemilihan Kriteria Berdasarkan Kota

3) Membuat matriks perbandingan berpasangan: memberikan penilaian kriteria dan alternatif kriteria dengan memberikan nilai dengan skala 1 sampai 9 berdasarkan Saaty's 1-9 Scale for AHP Preference [10]. Nilai dan definisi pendapat kualitatif dari skala perbandingan dapat diukur dengan menggunakan Tabel II.

4)

TABEL II

SKala PENILAIAN PERBANDINGAn BERPASANGAN

\begin{tabular}{|c|l|}
\hline $\begin{array}{c}\text { Intensitas } \\
\text { Kepentingan }\end{array}$ & \multicolumn{1}{c|}{ Keterangan } \\
\hline 1 & Kedua elemen sama pentingnya \\
\hline 3 & $\begin{array}{l}\text { Elemen yang satu sedikit lebih penting daripada } \\
\text { elemen yang lainnya }\end{array}$ \\
\hline
\end{tabular}




\begin{tabular}{|c|l|}
\hline 5 & $\begin{array}{l}\text { Elemen yang satu lebih penting daripada yang } \\
\text { lainnya }\end{array}$ \\
\hline 7 & $\begin{array}{l}\text { Satu elemen jelas lebih mutlak penting daripada } \\
\text { elemen lainnya }\end{array}$ \\
\hline 9 & $\begin{array}{l}\text { Satu elemen mutlak penting daripada elemen } \\
\text { lainnya }\end{array}$ \\
\hline $2,4,6,8$ & $\begin{array}{l}\text { Nilai-nilai antara dua nilai pertimbangan- } \\
\text { pertimbangan yang berdekatan }\end{array}$ \\
\hline
\end{tabular}

4) Menentukan prioritas: untuk setiap kriteria dan alternatif kriteria perlu dilakukan perbandingan berpasangan (pairwise comparison). Nilai-nilai perbandingan relatif dari seluruh alternatif kriteria bisa disesuaikan dengan judgement yang telah ditentukan untuk menghasilkan bobot dan prioritas. Bobot dan prioritas dihitung dengan memanipulasi matriks atau melalui penyelesaian persamaan matematika.

\section{A. Matrik Perbandingan Berpasangan}

Berdasarkan hasil survei, maka ditentukan nilai perbandingan berpasangan untuk masing-masing kriteria yang akan dihitung seperti pada Tabel III.

Penentuan nilai pada matriks ditentukan berdasarkan perbandingan tingkat kepentingan antara satu variabel dengan variabel lain.

TABEL III

MATRIKS BOBOT DATA KRITERIA

\begin{tabular}{|c|c|c|c|c|c|}
\hline & 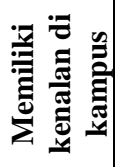 & 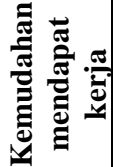 & 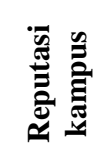 & 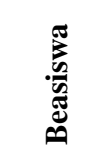 & 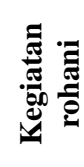 \\
\hline $\begin{array}{l}\text { Memiliki } \\
\text { kenalan di } \\
\text { kampus }\end{array}$ & 1 & 0,20 & 0,252 & 0,33 & 0,14 \\
\hline $\begin{array}{c}\text { Kemudahan } \\
\text { mendapat } \\
\text { kerja }\end{array}$ & 5,00 & 1 & 3,00 & 3,00 & 0,33 \\
\hline $\begin{array}{c}\text { Reputasi } \\
\text { kampus }\end{array}$ & 4,00 & 0,33 & 1 & 3,00 & 0,33 \\
\hline Beasiswa & 3,00 & 0,33 & 0,33 & 1 & 0,33 \\
\hline $\begin{array}{c}\text { Kegiatan } \\
\text { rohani }\end{array}$ & 7,00 & 3,00 & 3,00 & 3,00 & 1 \\
\hline Jumlah & 20,00 & 4,87 & 7,58 & 10,33 & 2,14 \\
\hline
\end{tabular}

Sebagai contoh dari hasil survei antara kegiatan rohani dengan kemudahan mendapat kerja tidak terlalu jauh selisihnya, sehingga diberi nilai 3 dengan kegiatan rohani lebih penting sedikit daripada kemudahan mendapat kerja, sedangkan pada sebaliknya diberikan nilai $1 / 3=0,33$.

Contoh lain dalam perhitungan, pada kriteria kegiatan rohani dibandingkan dengan kriteria memiliki kenalan di kampus, karena kegiatan rohani mutlak lebih penting dibandingkan dengan memiliki kenalan di kampus maka diberi nilai 7,00 , sedangkan untuk yang sebaliknya diberi angka 1 dibagi dengan 7 yaitu 0,14 . Hal ini dilakukan untuk semua kriteria pada baris dan kolom

Kolom yang paling bawah menunjukkan jumlah semua nilai pada masing-masing kriteria. Seperti pada kolom kriteria kegiatan rohani:

$$
0,14+0,33+0,33+0,33+1=2,14
$$

Selanjutnya pada Tabel IV, menggunakan nilai yang terdapat pada Tabel III, dibagi dengan jumlah total dari setiap kolom. Lalu rata-rata dari setiap baris menjadi nilai bobot untuk kriteria seperti yang tertulis pada kolom bobot.

Sebagai contoh untuk baris 1 dan kolom 1 mengenai kriteria memiliki kenalan di kampus, maka nilai 1 dibagi dengan 20 sebagai total kolom kriteria memiliki kenalan di kampus, sehingga didapatkan angkat 0,05.

Contoh lainnya dalam perhitungan, pada baris kriteria reputasi kampus dan kolom beasiswa terdapat nilai 3,00, lalu total jumlah kolom beasiswa sebesar 10,33, maka 3,00 dibagi dengan 10,33 sehingga dihasilkan nilai 0,29. Hal ini dilakukan untuk semua baris dan kolom, dan untuk memastikan bahwa perhitungan ini telah benar, bila setiap kolom dijumlahkan ke bawah maka hasil yang didapatkan adalah 1 .

TABEL IV

MATRIKS BOBOT DATA KRITERIA

\begin{tabular}{|c|c|c|c|c|c|c|}
\hline & 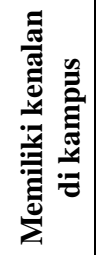 & 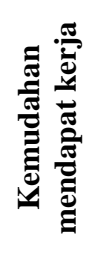 & 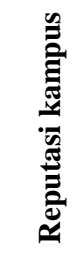 & 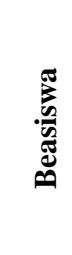 & 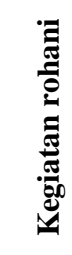 & $\frac{\overrightarrow{8}}{\ddot{0}}$ \\
\hline $\begin{array}{c}\text { Memiliki } \\
\text { kenalan di } \\
\text { kampus } \\
\end{array}$ & 0,05 & 0,04 & 0,03 & 0,03 & 0,07 & 0,04 \\
\hline $\begin{array}{c}\text { Kemudahan } \\
\text { mendapat } \\
\text { kerja }\end{array}$ & 0,25 & 0,21 & 0,40 & 0,29 & 0,16 & 0,26 \\
\hline $\begin{array}{c}\text { Reputasi } \\
\text { kampus }\end{array}$ & 0,20 & 0,07 & 0,13 & 0,29 & 0,16 & 0,17 \\
\hline Beasiswa & 0,15 & 0,07 & 0,04 & 0,10 & 0,16 & 0,10 \\
\hline $\begin{array}{c}\text { Kegiatan } \\
\text { rohani }\end{array}$ & 0,35 & 0,62 & 0,40 & 0,29 & 0,47 & 0,42 \\
\hline
\end{tabular}

Untuk menentukan nilai bobot, semua nilai yang telah didapatkan pada baris masing-masing kriteria diambil rataratanya. Sebagai contoh, untuk kriteria memiliki kenalan di kampus, maka perhitungannya:

$$
\frac{0,05+0,04+0,03+0,03+0,07}{5}=0,04
$$


Kemudian dilanjutkan dengan membuktikan bahwa nilai yang dimasukkan dalam matriks apakah telah konsisten. Caranya dengan mencari $\lambda_{\max }$ (eigen value) dengan rumus [11]:

$$
\lambda_{\text {max }}=\sum_{i=1}^{n}\left(\frac{a_{i j}}{w_{i}}\right) / n
$$

Mencari $\lambda_{\max }$ (eigen value) didapatkan dari eigen atau bobot yang didapat [12], pada Tabel IV terdapat lima bobot yang dihasilkan, sehingga cara menghitung $\lambda_{\max }$ adalah:

$$
\begin{aligned}
\lambda_{\max } & =\begin{array}{c}
(20 \times 0,04)+(4,87 \times 0,26)+(7,58 \times 0,17) \\
+
\end{array} \\
& =5,41
\end{aligned}
$$

Setelah menentukan $\lambda_{\max }$ (eigen value), maka perlu mencari besar consistency index (CI), hal ini dilakukan untuk nantinya mencari consistency ratio $(\mathrm{CR})$.

$$
\begin{aligned}
& C I=\frac{(\lambda \max -n)}{n} \\
& C I=\frac{5,41-5}{5}=0,08196462
\end{aligned}
$$

Didalam mencari consistency ratio (CR) dibutuhkan nilai index random (IR), berdasarkan Thomas L. Saaty [7] nilai IR seperti pada Tabel V. Maka perhitungan consistency ratio $(\mathrm{CR})$ adalah:

$$
\begin{gathered}
C R=\frac{C I}{I R} \\
C R=\frac{0,08196462}{1,12}=0,07
\end{gathered}
$$

TABEL V

\begin{tabular}{|c|c|} 
NILAI INDEX RANDOM SAATY \\
\hline $\mathbf{n}$ & IR \\
\hline $1 \& 2$ & 0,00 \\
\hline 3 & 0,58 \\
\hline 4 & 0,90 \\
\hline 5 & 1,12 \\
\hline 6 & 1,24 \\
\hline 7 & 1,32 \\
\hline 8 & 1,41 \\
\hline 9 & 1,45 \\
\hline
\end{tabular}

Maka dari hasil perhitungan didapatkan nilai CR adalah 0,07, berarti nilai perbandingan berpasangan yang dimasukkan konsisten, karena nilai $\mathrm{CR}=0,07<1$. Sehingga nilai bobot yang dihasilkan dapat digunakan dalam perhitungan.

\section{B. Matriks Kriteria Alternatif}

Dari kriteria yang telah dilakukan perhitungan dengan matriks perbandingan berpasangan tadi, maka dilanjutkan dengan menghitung matrik perbandingan berpasangan untuk 5 (lima) kota yang menjadi target pasar, yaitu Ambon, Kupang, Manado, Pekanbaru dan Pontianak.

Sepertinya halnya tadi, maka pembuatan matriks dengan memberikan nilai perbandingan berpasangan untuk

\begin{tabular}{|c|c|c|c|c|c|}
\hline & $\frac{\Xi}{\text { ह }}$ & 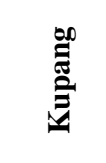 & 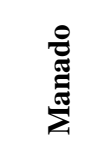 & 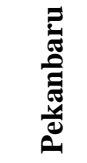 & 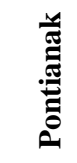 \\
\hline Ambon & 1 & 3,000 & 3,000 & 0,333 & 1,000 \\
\hline Kupang & 0,333 & 1 & 1,000 & 0,200 & 0,333 \\
\hline Manado & 0,333 & 1,000 & 1 & 0,200 & 0,333 \\
\hline Pekanbaru & 3,000 & 5,000 & 5,000 & 1 & 3,000 \\
\hline Pontianak & 1,000 & 3,000 & 3,000 & 0,333 & 1 \\
\hline Jumlah & 5,667 & 13,000 & 13,000 & 2,067 & 5,667 \\
\hline
\end{tabular}
keterkaitan antar kota. Untuk melihat keterkaitan berdasarkan hasil survei penerimaan mahasiswa baru yang memilih kriteria tersebut dan berasal dari kota yang akan diukur, seperti pada Tabel VI.

TABEL VI

MATRIKS BobOT DATA KRITERIA MEMILIKI KENALAN DI KAMPUS

Pemberian nilai dilakukan berdasarkan hasil survei, dimana perbandingan antar variabel menjadi pertimbangan untuk memberikan nilai berdasarkan tingkat kepentingannya. Hal ini dilakukan untuk semua kriteria dibandingkan dengan kota.

Sebagai contoh untuk kriteria memiliki kenalan di kampus, untuk kota Ambon dibandingkan dengan Kupang, karena Kupang lebih penting sedikit daripada Ambon untuk kriteria ini, maka diberikan nilai 3,00 di posisi dekat dengan Kupang. Sedangkan untuk posisi sebaliknya, dilakukan perhitungan 1 dibagi 3 , yaitu 0,333 . Pemberian nilai ini diberikan untuk semua baris dan kolom, kecuali untuk perbandingan dengan kota yang sama diberi nilai 1 .

Untuk perhitungan pada Tabel VII, seperti sebelumnya dengan mengisi hasil dari pembagian nilai pada Tabel VI dibagi dengan total jumlah kolom setiap kriteria. 
TABEL VII

MATRIKS Bobot DATA KRITERIA MEMILIKI KENALAN DI KAMPUS

\begin{tabular}{|c|c|c|c|c|c|c|}
\hline & 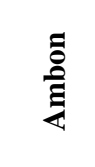 & 占 & 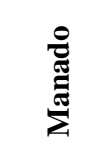 & 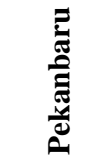 & 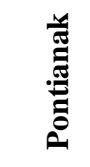 & 苛 \\
\hline Ambon & 0,176 & 0,231 & 0,231 & 0,161 & 0,176 & 0,195 \\
\hline Kupang & 0,059 & 0,077 & 0,077 & 0,097 & 0,059 & 0,074 \\
\hline Manado & 0,059 & 0,077 & 0,077 & 0,097 & 0,059 & 0,074 \\
\hline Pekanbaru & 0,176 & 0,231 & 0,231 & 0,161 & 0,176 & 0,462 \\
\hline Pontianak & 0,176 & 0,231 & 0,231 & 0,161 & 0,176 & 0,195 \\
\hline
\end{tabular}

Sebagai contoh untuk kota Ambon, hasil didapatkan dari 1 dibagi dengan 5,667, sehingga hasil yang didapatkan adalah 0,176. Sedangkan untuk mendapatkan bobot prioritas, merupakan rata-rata dari setiap kota pada baris, contohnya:

$$
\frac{0,176+0,231+0,231+0,161+0,176}{5}=0,195
$$

Setelah membuat matriks untuk kriteria memiliki kenalan di kampus, maka didapat bobot untuk masingmasing kota pada kriteria ini. Selanjutnya mengukur $\lambda_{\max }$ dengan rumus yang sama, yaitu:

$$
\begin{gathered}
{\left[\begin{array}{lllll}
5,667 & 13,000 & 13,000 & 2,067 & 5,667
\end{array}\right] x\left[\begin{array}{l}
0,195 \\
0,074 \\
0,074 \\
0,462 \\
0,195
\end{array}\right]} \\
\lambda_{\max }=5,08
\end{gathered}
$$

Kemudian diukur nilai consistency index (CI)

$$
C I=\frac{(\lambda \max -n)}{n}=\frac{5,08-5}{5}=0,0164663
$$

Sama seperti tadi, selanjutnya menghitung consistency ratio (CR)

$$
C R=\frac{C I}{I R}=\frac{0,0164663}{1,12}=0,01
$$

Maka untuk kriteria beasiswa sudah konsisten, karena nilai CR yang didapatkan $0,01<1$ (kurang dari pada satu). Sehingga data ini dapat digunakan.

Perhitungan dengan membuat matriks berpasangan dilakukan untuk semua kriteria, dan dihitung hingga menemukan CR untuk masing-masing kriteria, agar dapat di validasi bahwa nilai yang dimasukkan dalam matriks sudah konsisten. Berikut perhitungan untuk kriteria kemudahan mendapat kerja seperti pada Tabel VIII. Sebagai contoh untuk kota Pekanbaru dibandingkan dengan Kupang diberi bobot 5 (lima), karena di kota Pekanbaru kriteria

\begin{tabular}{|c|c|c|c|c|c|}
\hline & $\frac{\Xi}{\mathrm{E}}$ & 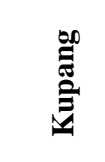 & 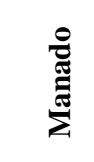 & 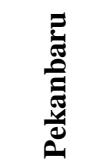 & 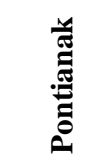 \\
\hline Ambon & 1 & 2,000 & 1,000 & 0,333 & 1,000 \\
\hline Kupang & 0,500 & 1 & 0,500 & 0,200 & 0,500 \\
\hline Manado & 1,000 & 2,000 & 1 & 0,250 & 3,000 \\
\hline Pekanbaru & 3,000 & 5,000 & 4,000 & 1 & 5,000 \\
\hline Pontianak & 1,000 & 2,000 & 1,000 & 0,200 & 1 \\
\hline Jumlah & 6,500 & 12,000 & 7,500 & 1,983 & 10,500 \\
\hline
\end{tabular}
kemudahan mendapat kerja lebih penting dibandingkan dengan kota Kupang.

TABEL VIII

MATRIKS BOBOT DATA KRITERIA KEMUdAHAN MENDAPAT KERJA

Kemudian dari bobot yang telah didapatkan, untuk mencari bobot prioritas dari masing-masing kota dilakukan dengan membagi antara bobot kota dengan jumlah kolom dari kota tersebut. Sebagai contoh seperti pada Tabel IX,

\begin{tabular}{|c|c|c|c|c|c|c|}
\hline & $\frac{\mathfrak{8}}{\mathrm{E}}$ & 照 & 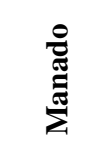 & 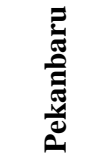 & 㺼 & 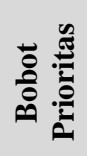 \\
\hline Ambon & 0,154 & 0,167 & 0,133 & 0,168 & 0,095 & 0,143 \\
\hline Kupang & 0,077 & 0,083 & 0,067 & 0,101 & 0,048 & 0,075 \\
\hline Manado & 0,154 & 0,167 & 0,133 & 0,126 & 0,286 & 0,173 \\
\hline Pekanbaru & 0,462 & 0,417 & 0,533 & 0,504 & 0,476 & 0,478 \\
\hline Pontianak & 0,154 & 0,167 & 0,133 & 0,101 & 0,095 & 0,130 \\
\hline
\end{tabular}
untuk kota Kupang dibandingkan dengan Ambon adalah 0,500 dibagi dengan 6,500, sehingga didapatkan hasil 0,077.

TABEL IX

MATRIKS BOBOT DATA KRITERIA KEMUdAHAN MENDAPAT KERJA 
Setelah bobot prioritas untuk kriteria kemudahan mendapat kerja didapatkan, selanjutnya mengukur $\lambda_{\max }$, yaitu:

$$
\begin{gathered}
{\left[\begin{array}{lllll}
6,500 & 12,000 & 7,500 & 1,983 & 10,500
\end{array}\right] x\left[\begin{array}{l}
0,143 \\
0,075 \\
0,173 \\
0,478 \\
0,130
\end{array}\right]} \\
\lambda_{\text {max }}=5,45
\end{gathered}
$$

Kemudian dilakukan pengukuran untuk mendapatkan nilai consistency index $(\mathrm{CI})$

$$
C I=\frac{(\lambda \max -n)}{n}=\frac{5,45-5}{5}=0,089054378
$$

Selanjutnya menghitung consistency ratio (CR)

$$
C R=\frac{C I}{I R}=\frac{0,089054378}{1,12}=0,08
$$

Maka untuk kriteria kemudahan mendapat kerja nilai CR yang didapatkan $0,08<1$ (kurang dari pada satu). Sehingga data dikatakan konsisten dan dapat digunakan untuk mendapatkan bobot akhir.

Untuk kriteria reputasi kampus, dilakukan perhitungan yang sama untuk memberikan bobot perbandingan antar

\begin{tabular}{|c|c|c|c|c|c|}
\hline & $\begin{array}{l}\text { हี } \\
\stackrel{\Xi}{\sharp}\end{array}$ & 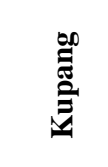 & 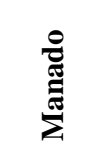 & 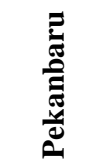 & 瓷 \\
\hline Ambon & 1 & 0,333 & 0,200 & 0,200 & 0,143 \\
\hline Kupang & 3,000 & 1 & 0,333 & 0,500 & 0,200 \\
\hline Manado & 5,000 & 3,000 & 1 & 1,000 & 0,250 \\
\hline Pekanbaru & 5,000 & 2,000 & 1,000 & 1 & 0,250 \\
\hline Pontianak & 7,000 & 5,000 & 4,000 & 4,000 & 1 \\
\hline Jumlah & 21,000 & 11,333 & 6,533 & 6,700 & 1,843 \\
\hline
\end{tabular}
kota seperti pada Tabel X.

TABEL $X$

MATRIKS BOBOT DATA KRITERIA REPUTASI KAMPUS

Selanjutnya pada Tabel XI menghitung bobot prioritas dari masing-masing kota terhadap kriteria reputasi kampus. Sebagai contoh untuk baris Pontianak dengan kolom Ambon, hasil didapatkan dari bobot 7,000 dibagi dengan jumlah kolom kota Ambon 21,000, sehingga hasil yang didapatkan

\begin{tabular}{|c|c|c|c|c|c|c|}
\hline & $\frac{\Xi}{\Xi}$ & 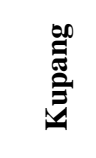 & 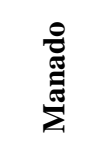 & 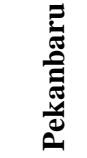 & مِ & 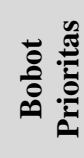 \\
\hline Ambon & 0,048 & 0,029 & 0,031 & 0,030 & 0,078 & 0,043 \\
\hline Kupang & 0,143 & 0,088 & 0,051 & 0,075 & 0,190 & 0,093 \\
\hline Manado & 0,238 & 0,265 & 0,153 & 0,149 & 0,136 & 0,188 \\
\hline Pekanbaru & 0,238 & 0,176 & 0,153 & 0,149 & 0,136 & 0,188 \\
\hline Pontianak & 0,333 & 0,441 & 0,612 & 0,597 & 0,543 & 0,505 \\
\hline
\end{tabular}
0,333 .

TABEL XI

MATRIKS BOBOT DATA KRITERIA REPUTASI KAMPUS

Untuk kriteria kemudahan mendapat kerja bobot prioritas yang telah didapatkan untuk mengukur $\lambda_{\max }$, yaitu:

$$
\begin{aligned}
& {\left[\begin{array}{lllll}
21,000 & 11,333 & 6,533 & 6,700 & 1,843
\end{array}\right] x\left[\begin{array}{l}
0,043 \\
0,093 \\
0,188 \\
0,171 \\
0,505
\end{array}\right]} \\
& \lambda_{\text {max }}=5,26
\end{aligned}
$$

Kemudian diukur nilai consistency index (CI)

$$
C I=\frac{(\lambda \max -n)}{n}=\frac{5,26-5}{5}=0,052100707
$$

Selanjutnya menghitung consistency ratio $(\mathrm{CR})$

$$
C R=\frac{C I}{I R}=\frac{0,052100707}{1,12}=0,05
$$

Maka untuk kriteria kemudahan mendapat kerja sudah konsisten, karena nilai CR yang didapatkan $0,05<1$ (kurang dari pada satu). Sehingga data ini dapat digunakan untuk mendapatkan bobot akhir.

Untuk kriteria beasiswa, pemberian bobot pada masingmasing kota dilakukan seperti pada kriteria lainnya. Pada Tabel XII ada sedikit perbedaan untuk bobot antara kota Manado dengan Kupang diberi bobot 2,000, karena kota Manado hanya lebih penting sedikit daripada kota Kupang. 
TABEL XII

MATRIKS BOBOT DATA KRITERIA BEASISWA

\begin{tabular}{|c|c|c|c|c|c|}
\hline & 泀 & 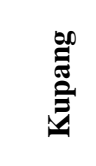 & 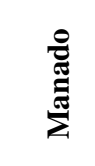 & 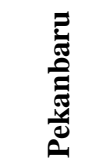 & \\
\hline Ambon & 1 & 0,333 & 0,250 & 0,500 & 1,000 \\
\hline Kupang & 3,000 & 1 & 0,500 & 0,500 & 3,000 \\
\hline Manado & 4,000 & 2,000 & 1 & 3,000 & 3,000 \\
\hline Pekanbaru & 2,000 & 2,000 & 0,333 & 1 & 4,000 \\
\hline Pontianak & 1,000 & 0,333 & 0,333 & 0,250 & 1 \\
\hline Jumlah & 11,000 & 5,667 & 2,417 & 5,250 & 12,000 \\
\hline
\end{tabular}

Untuk menentukan bobot prioritas pada kriteria beasiswa, dilakukan perhitungan yang sama dengan kriteria lainnya, dan hasil yang didapatkan seperti pada Tabel XIII.

TABEL XIII

MATRIKS BOBOT DATA KRITERIA BEASISWA

\begin{tabular}{|c|c|c|c|c|c|c|}
\hline & $\frac{\mathrm{E}}{\mathrm{E}}$ & 点 & 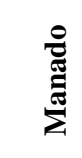 & 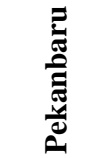 & مِ & 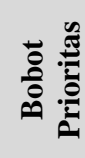 \\
\hline Ambon & 0,091 & 0,059 & 0,103 & 0,095 & 0,083 & 0,086 \\
\hline Kupang & 0,273 & 0,176 & 0,207 & 0,095 & 0,250 & 0,200 \\
\hline Manado & 0,364 & 0,353 & 0,414 & 0,571 & 0,250 & 0,390 \\
\hline Pekanbaru & 0,182 & 0,353 & 0,138 & 0,190 & 0,333 & 0,239 \\
\hline Pontianak & 0,091 & 0,059 & 0,138 & 0,048 & 0,083 & 0,084 \\
\hline
\end{tabular}

Untuk kriteria kemudahan mendapat kerja, selanjutnya mengukur $\lambda_{\max }$, yaitu:

$$
\left.\begin{array}{ccccc}
11,000 & 5,667 & 2,417 & 5,250 & 12,000
\end{array}\right] x\left[\begin{array}{l}
0,086 \\
0,200 \\
0,390 \\
0,239 \\
0,084
\end{array}\right]
$$

Kemudian diukur nilai consistency index (CI)

$$
C I=\frac{(\lambda \max -n)}{n}=\frac{5,29-5}{5}=0,057814328
$$

Selanjutnya menghitung consistency ratio $(\mathrm{CR})$

$$
C R=\frac{C I}{I R}=\frac{0,057814328}{1,12}=0,05
$$

Maka untuk kriteria kemudahan mendapat kerja nilai CR yang didapatkan $0,05<1$ (kurang dari pada satu). Sehingga data ini dinyatakan konsisten dan dapat digunakan untuk mendapatkan bobot akhir.

Terakhir untuk kriteria kegiatan rohani perlu dihitung matriks perbandingan berpasangan seperti pada Tabel XIV. Dengan melakukan perhitungan yang sama, setiap kolom dan baris diberikan nilai berdasarkan tingkat kepentingan

\begin{tabular}{|c|c|c|c|c|c|}
\hline & $\frac{\mathrm{E}}{\mathrm{E}}$ & 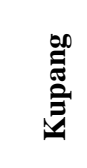 & 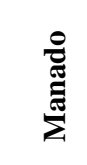 & 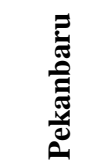 & 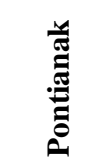 \\
\hline Ambon & 1 & 0,333 & 2,000 & 7,000 & 3,000 \\
\hline Kupang & 3,000 & 1 & 4,000 & 7,000 & 5,000 \\
\hline Manado & 0,500 & 0,250 & 1 & 4,000 & 2,000 \\
\hline Pekanbaru & 0,143 & 0,143 & 0,250 & 1 & 0,250 \\
\hline Pontianak & 0,333 & 0,200 & 0,500 & 4,000 & 1 \\
\hline Jumlah & 4,976 & 1,926 & 7,750 & 23,000 & 11,250 \\
\hline
\end{tabular}
antar kriteria yang dihitung.

TABEL XIV

MATRIKS BOBOT DATA KRITERIA KEGIATAN ROHANI

Berdasarkan hasil survei, untuk kota Pekanbaru dan Pontianak cukup dominan yang mengisi kegiatan rohani sebagai faktor yang paling penting, sehingga nilai yang diberikan menjadi lebih besar dibandingkan tiga kota lainnya. Pada Tabel XV, ditentukan bobot prioritas dari

\begin{tabular}{|c|c|c|c|c|c|c|}
\hline & $\frac{\Xi}{\Xi}$ & 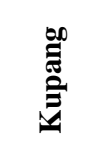 & 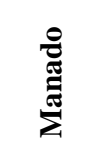 & 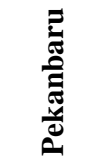 & م્ & 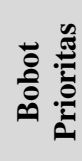 \\
\hline Ambon & 0,201 & 0,173 & 0,258 & 0,304 & 0,267 & 0,241 \\
\hline Kupang & 0,603 & 0,519 & 0,516 & 0,304 & 0,444 & 0,477 \\
\hline
\end{tabular}
rata-rata setiap kota.

TABEL XV

MATRIKS BOBOT DATA KRITERIA KEGIATAN ROHANI 


\begin{tabular}{|c|c|c|c|c|c|c|}
\hline & $\begin{array}{l}\text { है } \\
\text { है }\end{array}$ & 占 & & 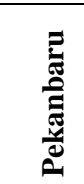 & 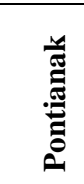 & 总 \\
\hline Manado & 0,100 & 0,130 & 0,129 & 0,174 & 0,178 & 0,142 \\
\hline Pekanbaru & 0,029 & 0,074 & 0,032 & 0,043 & 0,022 & 0,040 \\
\hline Pontianak & 0,067 & 0,104 & 0,065 & 0,174 & 0,089 & 0,100 \\
\hline
\end{tabular}

Untuk kriteria kemudahan mendapat kerja, selanjutnya mengukur $\lambda_{\max }$, yaitu:

$$
\begin{gathered}
{\left[\begin{array}{ccccc}
4,976 & 1,926 & 7,750 & 23,000 & 11,250
\end{array}\right] x\left[\begin{array}{l}
0,241 \\
0,477 \\
0,142 \\
0,040 \\
0,100
\end{array}\right]} \\
\lambda_{\text {max }}=5,26
\end{gathered}
$$

Kemudian diukur nilai consistency index (CI)

$$
C I=\frac{(\lambda \max -n)}{n}=\frac{5,26-5}{5}=0,052715046
$$

Selanjutnya menghitung consistency ratio (CR)

$$
C R=\frac{C I}{I R}=\frac{0,052715046}{1,12}=0,05
$$

Maka untuk kriteria kemudahan mendapat kerja sudah konsisten, karena nilai CR yang didapatkan $0,05<1$ (kurang dari pada satu). Sehingga data ini dapat digunakan untuk mendapatkan bobot akhir.

\section{Memperoleh Vektor Prioritas}

Dengan berdasarkan hasil bobot prioritas sebelumnya, maka bobot setiap alternatif kriteria yang telah dihitung, dikalikan kedua matriks untuk mendapatkan bobot akhir. Dimana dari hasil bobot akhir ini dapat ditentukan tingkat

\begin{tabular}{|c|c|c|c|c|c|}
\hline & 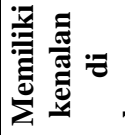 & 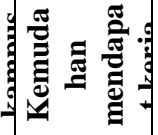 & 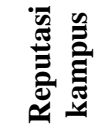 & 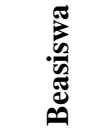 & 司 \\
\hline Ambon & 0,195 & 0,143 & 0,043 & 0,086 & 0,241 \\
\hline Kupang & 0,074 & 0,075 & 0,093 & 0,200 & 0,477 \\
\hline
\end{tabular}
prioritasnya.

\begin{tabular}{|c|c|c|c|c|c|}
\hline & 总 & 蛋 & 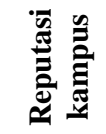 & 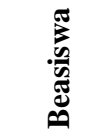 & 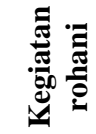 \\
\hline Manado & 0,074 & 0,173 & 0,188 & 0,390 & 0,142 \\
\hline Pekanbaru & 0,462 & 0,478 & 0,171 & 0,239 & 0,040 \\
\hline Pontianak & 0,195 & 0,130 & 0,505 & 0,084 & 0,100 \\
\hline
\end{tabular}

TABEL XVI

MATRIX HASIL KRITERIA ALTERNATIF
TABEL XVII

MATRIX HASIL PERBANDINGAN BERPASANGAN

\begin{tabular}{|c|c|}
\hline Kriteria & Bobot \\
\hline Memiliki kenalan di kampus & 0,04 \\
\hline Kemudahan mendapat kerja & 0,26 \\
\hline Reputasi kampus & 0,17 \\
\hline Beasiswa & 0,10 \\
\hline Kegiatan rohani & 0,42 \\
\hline
\end{tabular}

Kedua matriks pada Tabel XVI dan Tabel XVII dikalikan dengan perhitungan seperti [13]:

$\left[\begin{array}{lllll}0,195 & 0,143 & 0,043 & 0,086 & 0,241 \\ 0,074 & 0,075 & 0,093 & 0,200 & 0,200 \\ 0,074 & 0,173 & 0,188 & 0,390 & 0,390 \\ 0,462 & 0,478 & 0,171 & 0,239 & 0,239 \\ 0,195 & 0,130 & 0,505 & 0,084 & 0,084\end{array}\right] \times\left[\begin{array}{l}0,04 \\ 0,26 \\ 0,17 \\ 0,10 \\ 0,42\end{array}\right]$

Sehingga hasil yang didapat dari perkalian dua matriks ini adalah seperti pada Tabel XVIII, dimana dengan bobot itu dilakukan perangkingan untuk mengetahui kriteria mana yang paling berpengaruh terhadap calon mahasiswa dalam memilih perguruan tinggi.

TABEL XVIII

BOBOT AKHIR

\begin{tabular}{|c|c|c|}
\hline Kriteria & Bobot Akhir & Perangkingan \\
\hline $\begin{array}{c}\text { Kemudahan mendapat } \\
\text { kerja }\end{array}$ & 0,261447786 & 1 \\
\hline Beasiswa & 0,215229186 & 3 \\
\hline Reputasi kampus & 0,180490521 & 4 \\
\hline $\begin{array}{c}\text { Kegiatan rohani } \\
\text { Memiliki kenalan di } \\
\text { kampus }\end{array}$ & 0,178780635 & 5 \\
\hline
\end{tabular}


Maka setelah mendapatkan hasil secara keseluruhan, hasilnya kemudahan mendapat kerja merupakan faktor yang paling mempengaruhi calon mahasiswa dalam memilih perguruan tinggi, kemudian disusul dengan beasiswa sebagai urutan kedua.

\section{KESIMPULAN}

Pada penelitian ini dapat terlihat, bahwa kriteria kemudahan mendapat kerja menjadi yang tertinggi atau prioritas bagi calon mahasiswa dalam memilih perguruan tinggi, selanjutnya peringkat kriteria yang didapatkan adalah beasiswa, reputasi kampus, kegiatan rohani dan memiliki kenalan di kampus.

Dengan mengukur setiap kriteria dengan matriks dan menemukan consistency ratio (CR) yang lebih kecil daripada 1 (satu), hasil ini memberikan validasi bahwa bobot yang diberikan pada setiap kriteria telah konsisten dalam keterkaitan antar kriteria, dan juga antara kriteria dengan target kota.

Untuk setiap target kota yang dituju memiliki kriteria yang berbeda-beda, hal ini memperlihatkan bahwa untuk menerapkan strategi pemasaran yang tepat perlu lebih spesifik sesuai kebutuhan target pasar yang dituju. Seperti kota Ambon dan Kupang, kriteria kegiatan rohani sebagai faktor yang paling berpengaruh dalam memilih perguruan tinggi. Hal ini mungkin terjadi, karena dua kota ini cukup kuat dengan faktor kerohaniannya.

Untuk kota Manado, kriteria beasiswa menjadi faktor yang paling berpengaruh dalam memilih perguruan tinggi. Sehingga untuk mendapatkan calon mahasiswa dari kota Manado, perlu mempromosikan dengan beasiswa yang ditawarkan.

Sedangkan di kota Pekanbaru, kriteria kemudahan mendapat kerja menjadi yang paling besar bobotnya, ditambah dengan memiliki kenalan di kampus tidak jauh berbeda bobotnya. Sehingga ini menjadi cara yang lebih tepat untuk ditawarkan kepada calon mahasiswa dari kota Pekanbaru.

Untuk kota Pontianak, reputasi kampus menjadi kriteria yang paling menonjol dibandingkan kriteria lainnya. Sehingga untuk kampus yang sudah memiliki reputasi kampus akan menjadi daya tarik bagi calon mahasiswa dari Pontianak.

Jadi dalam mengambil keputusan dalam menentukan strategi pemasaran di masing-masing kota, perlu ditawarkan dengan kriteria yang paling besar dari hasil bobot yang dihasilkan dengan AHP. Sehingga promosi yang dilakukan akan lebih sesuai dengan kebutuhan calon mahasiswa, dengan ini dapat membantu meningkatkan jumlah pendaftar ke perguruan tinggi.
Dengan penelitian ini diharapkan dapat membantu perguruan tinggi untuk mengambil keputusan dalam menentukan strategi Pemasaran di masing-masing kota, karena dari hasil penelitian setiap kota memiliki faktor yang berbeda-beda. Dengan mengetahui faktor apa yang menjadi penentu akan menambah penetrasi terhadap target pasar yang dituju.

\section{DAFTAR PUSTAKA}

[1] (2018) Pusat Data dan Statistik Kementerian Pendidikan dan Kebudayaan website, [Online]. Tersedia: http//statistik.data.kemdikbud.go.id/.

[2] Dwi Hadya Jayani (2019), Databoks homepage, [Online]. Tersedia: https://databoks.katadata.co.id/datapublish/2019/09/26/tertinggisejak-1997-jumlah-mahasiswa-indonesia-2018-capai-7-juta-jiwa/.

[3] Kanda Seehanate, "The Marketing Factors Affecting Student's Decision of Choosing Higher Education Institution in SouthNortheastern Region", Review of Integrative Business and Economics Research, vol. 6, pp. 275-283, 2017.

[4] Aydar M. Kalimullin, Svetlana G. Dobrotvorskaya, "Higher Education Marketing Strategies Based on Factors Impacting the Enrollees' Choice of a University and an Academic Program", International Journal of Environmental \& Science Education, vol. 11, pp. 6025-6040, 2016.

[5] Can Deniz Koksal, N. Metin Ozmutaf, "Using Analytic Hierarchy Process for Selecting The Appropriate Host Country to Study English Language Abroad", International Journal of Social Sciences and Humanity Studies, vol. 1, no.1, pp. 37-46, 2009

[6] Chan WK, Tong TKL," Multi-criteria material selections and endof-life product strategy: Grey relational analysis approach", Elsevier Material \& Design, vol. 28, Issue 5, pp. 1539-1546, 2007.

[7] Thomas L. Saaty, Decision Making with The Analytic Hierarchy Process, Int. J. Services Sciences, vol.1, no.1, 2008.

[8] Davies, Mark A. P., "Using the AHP in marketing decision making", Journal of Marketing Management, vol. 10, pp. 57-73, 2010.

[9] Tuncay G., Y. Esra Albayrak, Elif Alaybeyoglu, "Criteria Weighting and 4P's Planning in Marketing Using a Fruzzy Distance and AHP Hybrid Method", International Journal of Computational Intelligence System, vol. 7 Supplement 1, pp. 94-104, 2013.

[10] Eddie W.L. Cheng, Heng Li, "Analytic hierarchy process: An approach to determine measures for business performance", ResearchGate, vol. 5, no. 3, pp. 30-37, 2001.

[11] Feriyanto (2018), Manajemen Industri headline on Sains, Teknologi dan Bisnis, [Online]. Tersedia: https://www.caesarvery.com/2018/10/metode-analytic-hierarchyprocess-ahp.html.

[12] Thomas L. Saaty, "Decision-making with the AHP: Why is the principal eigenvector necessary", European Journal of Operational Research, vol. 145 no.1, pp. 85-91, 2003.

[13] Sriyadi Narti, Nur Rahmayani, Mahmud Syarif, "Pengambilan Keputusan Memilih Sekolah Dengan Metode AHP”, Jurnal Informatika, vol. 6, no. 1, pp. 143-150, 2019.

[14] Hsuan-Fu Ho, Chia-Chi Hung, "Marketing Mix Formulation for Higher Education: An Integrated Analysis Employing Analytic Hierarchy Process, Clustrer Analysis and Correspondence Analysis", International Journal of Educational Management, vol. 22 no. 4, pp. 328-340, 2008.

[15] Veeris Ammarapala, Thanwadee Chinda, Pimnapa Pongsayaporn, Wit Ratanachot, "Cross-border Shipment Route Selection Utilizing Analytic Hierarchy Process (AHP) Method", Songklanakarin Journal of Science and Technology, vol. 40 no.1, pp. 31-37, 2018. 